\title{
Л.3. Ахметжан
}

Евразийский национальный университет им. Л.Н. Гумилева, Казахстан, г. Нур-Султан, e-mail: lauera.zakey@gmail.com

\section{ВАИЯНИЕ РАЗВИТИЯ ПРОИЗВОАСТВЕННОЙ АЕМОКРАТИИ НА УРОВЕНЬ ОХРАНЫ ТРУАА В КАЗАХСТАНСКИХ ОРГАНИЗАЦИЯХ В УСАОВИЯХ ЭКОНОМИЧЕСКОГО КРИЗИСА}

\begin{abstract}
В настоящеевремясложияасьситуация, когАапринятиеважнейшихрешений, непосредственно касающихся работников, является неотъемлемой прерогативой работодателя. И это в то время, когАа в зарубежных странах сложилась эффективная система участия работников в управлении организацией, которая напрямую ведет к повышению эффективности охраны труда. Целью работы является выявление характера влияния уровня развития элементов производственной Аемократии на эффективность вопросов охраны труда и каАрового менеАжмента в казахстанских организациях. В статье приведен митературный обзор научных исследований, посвященных влиянию производственной демократии на уровень защиты прав работников в организации. Также приведены результаты авторского исследования данного вопроса в казахстанских организациях, функционирующих в кризисных условиях. Экономический кризис, как правило, ведет к сокращению персонала организаций с нарушением трудового законодательства, что повышает достоверность полученных результатов. Методология заключается в анкетировании работников казахстанских компаний по вопросам развития элементов производственной Аемократии, разделение на Аве группы (с отсутствием элементов производственной демократии и с наличием) и сравнительный анализ показателей охраны труда в условиях экономического кризиса. В результате исследования была определена взаимосвязь и гипотеза о том, что элементы производственной демократии положительной влияют на практику охраны труда, подтвердилась. Практическая ценность заключается в создании доказательной основы Аля начала реализации проектов по развитию производственной демократии как на макро-, так и на микроуровне. Результаты могут быть использованы как обоснование законодательных инициатив по развития правовой базы производственной демократии в Республике Казахстан.
\end{abstract}

Ключевые слова: трудовые отношения, права работников, производственная демократия.

$$
\begin{aligned}
& \text { L.Z. Akhmetzhan } \\
& \text { L.N. Gumilyov Eurasian National University, Kazakhstan, Nur-Sultan, } \\
& \text { e-mail: lauera.zakey@gmail.com } \\
& \text { The impact of the development of industrial democracy } \\
& \text { on the level of labor protection in Kazakhstani organizations in the conditions } \\
& \text { of the economic crisis }
\end{aligned}
$$

Currently, a situation has emerged when making the most important decisions directly related to employees is an inalienable prerogative of the employer. And this at a time when in foreign countries there was an effective system of employee participation in the management of an organization, which directly leads to an increase in the efficiency of labor protection. The aim of the work is to identify the nature of the influence of the level of development of elements of industrial democracy on the effectiveness of labor protection and personnel management in Kazakhstani organizations. The article provides a literary review of scientific research devoted to the impact of industrial democracy on the level of protection of workers' rights in an organization. The results of the author's research of this issue in Kazakhstani organizations operating in crisis conditions are also presented. The economic crisis, as a rule, leads to a reduction in the personnel of organizations in violation of labor legislation, which increases the reliability of the results obtained. The methodology consists in a questionnaire survey of employees of Kazakhstani companies on the development of elements of industrial democracy, division into two groups (with the absence of elements of industrial democracy and with the presence) and a comparative analysis of labor protection indicators in the context of the economic crisis. As a result of the study, the relationship was determined and the hypothesis that the elements of industrial democracy have a positive effect on the practice of labor protection was confirmed. The practical value lies in creating an evidence base for starting the implementation of projects for the development of industrial democracy at both the macro and 
micro levels. The results can be used as a substantiation of legislative initiatives for the development of the legal framework of industrial democracy in the Republic of Kazakhstan.

Key words: labor relations, workers' rights, industrial democracy.

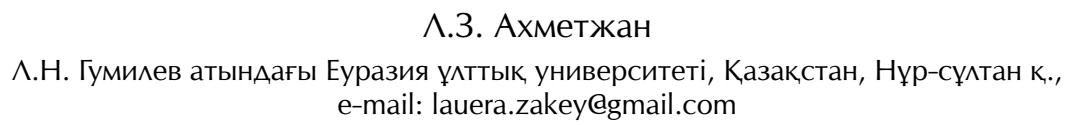

Экономикалық дағдарыс кезеңінде қазақстандық ұйымдарда өндіріс демократиясының дамуының еңбектік қорғау деңгейіне тигізетін әсері

\begin{abstract}
Қазіргі уақытта жұмысшыларға тікелей қатысты ең маңызды шешімдер қабылдау жұмыс берушінің ажырамас құқығы болатын жағдай туындады. Шетелдерде қызметкерлердің ұйымды басқаруға қатысуының тиімді жүйесі қалыптасқан, бұл тікелей еңбекті қорғау тиімділігінің артуына әкеледі. Жұмыстың мақсаты - өндірістік ұйымдардағы қызметкерлерді басқару және еңбекті қорғау тиімділігіне өндірістік Аемократия элементтерінің Ааму деңгейінің әсер ету сипатын анықтау. Мақалада өндірістік демократияның ұйымдағы жұмысшылардың құқықтарын қорғау деңгейі әсеріне арналған ғылыми зерттеулерге әдеби шолу жасалған. Аағдарыс жағдайында жұмыс істейтін қазақстандық ұйымдарда осы мәселені авторлық зерттеу нәтижелері де ұсынылған. Экономикалық дағдарыс ереже бойынша еңбек заңнамасын бұзатын ұйымдардың штатын қысқартуға алып келеді, бұл алынған нәтижелердің сенімділігін арттырады. Әдістеме қазақстандық компаниялар қызметкерлерінің өндірістік демократия элементтерін Аамыту туралы сауалнамасынан, екі топқа бөлінуінен (өндірістік демократия элементтерінің жоқтығымен және қатысуымен) және экономикалық, дағдарыс жағдайында контекстегі еңбекті қорғау көрсеткіштерін салыстырмалы та^даудан тұрады. Зерттеу нәтижесінде өзара байланыс анықталып, өндірістік демократия элементтері еңбекті қорғау практикасына оң әсер етеді деген болжам расталды. Практикалық мәні - макро және микродеңгейде де индустриялық, демократияны дамыту жобаларын іске асыруды бастау үшін дәлелді база құру. Нәтижелерді Қазақстан Республикасында өндірістік демократияның құқықтық базасын дамыту бойынша заңнамалық бастамалардың негіздемесі ретінде пайдалануға болады.

Түйін сөздер: еңбек қатынастары, жұмысшылардың құқықтары, өндірістік демократия.
\end{abstract}

\section{Введение}

Актуальность исследования заключается в том, что постсоветские государства, в том числе и Республика Казахстан, несмотря на вхождение в МOT, значительно отстают, иногда немного игнорируют необходимость обеспечения правовой базы для развития производственной демократии. Например, отсутствие легального определения термина «участие работников в управлении организацией» ведет либо к расширительному толкованию этого термина, либо, наоборот, слишком узкому толкованию и не позволяет понимать под ним что-либо иное, кроме административного управления производством.

В самой системе участия в управлении организацией основной формой взаимодействия является участие работников в процессах подготовки и принятия управленческих решений, равно как и контроля за их реализацией. Эта форма обеспечивает информационное взаимодействие работодателей с работниками организации и создает базу для их более тесного сотрудничества.
В мировой практике развитие производственной демократии стало возможным благодаря качественно новому этапу в развитии современного производства, которое характеризуется преимущественной ориентацией на работника. Складывается новая модель трудовых отношений, которая предусматривает изменение места и роли работника в трудовом процессе. Процесс становления новых управленческих бизнес процессов сопровождает и изменения в характере труда и обусловленных ими сдвигов в качественном состоянии рабочей силы.

Цель исследования - определение характера влияния развития элементов производственной демократии на качество охраны труда сотрудников.

Объект исследования - работники казахстанских организаций.

Предмет исследования - процесс развития производственной демократии и практики охраны труда в Казахстане.

\section{Задачи:}

- провести литературный обзор научных исследований, посвященных поиску взаимосвязей 
между развитием производственной демократии и показателями деятельности организаций;

- провести анкетирование и анализ результатов по вопросам развития производственной демократии в Казахстане;

- провести сравнительный анализ качества охраны труда и развития элементов производственной демократии;

- разработать рекомендации по развитию производственной демократии в Казахстане.

Гипотеза исследования: автор считает, что развитые элементы производственной демократии (в чистом виде ее нет в Казахстане) положительно влияют на показатели охраны труда в условиях экономического кризиса, как катализатора негативных процессов в системе управления персоналом.

\section{Материалы и методы}

Методы исследования: анкетирование, сравнительный анализ, анализ показателей охраны труда.

Процесс исследования поделен на следующие основные этапы:

Первый этап - формулировка гипотезы и целевой аудитории для проведения опроса.

Второй этап - составление анкеты для опроса респондентов.

Третий этап - проведение опроса с привлечением профсоюзных организаций Республики Казахстан.

Четвертый этап - сбор и сведение результатов анкетирования.

Пятый этап - анализ данных и формулировка выводов по проведенным исследовательским работам: ответы на исследовательские вопросы.

Шестой этап - сбор показателей по вопросам охраны труда и проведение сравнительного анализа по группам организаций.

Основным источником информации по исследуемой теме стали результаты анкетирования (и интервьюирования) респондентов.

Целевая аудитория представлена работниками казахстанских предприятий: сотрудники 45 предприятий (в некоторых из которых развиты элементы института участия работников в управлении предприятием, в другой - неразвиты); 500 респондентов, отобранных произвольно из казахстанских предприятий.

Цель анкетирования: определить уровень готовности работников и работодателей к внедрению производственной демократии.
В начале анкеты была разбивка на возраст и пол респондентов, а также в рамках исследования выделены сектора экономики.

Анкета была разделены на 2 вопросных блока:

- 1 вопросный блок «Анализ возможных путей развития производственной демократии в казахстанских компаниях» был направлен на определение готовности респондента участвовать в мероприятиях по развитию производственной демократии;

- 2 вопросный блок «Оценка уровня производственной демократии в вашей компании» имел целью выявить, как по мнению респондентов повлияет внедрение элементов производственной демократии на организацию.

Данное анкетирование проводилось в рамках написания диссертации и нами взяты для анализа результаты по второму блоку вопросов. Вопросы представляют из себя определенные высказывания, на которые надо дать ответ, насколько согласен или не согласен с предложенными высказываниями. Участвовавшим в опросе респондентам также было предложено прокомментировать ответы или дать более развернутый ответ, пример из практики, если односложного ответа недостаточно для передачи информации, которая важна по его мнению (метод интервьюирования).

Процесс сбора информации и заполнения вопросов анкеты проходил при помощи телефонного опроса респондентов, электронных писем с просьбой заполнить анкету. Казахстанские предприниматели и работники предприятий охотно принимали участие в опросе. Определенных проблем или сложностей не возникало, так как опрос проводился анонимно. С поиском респондентов сложностей также не возникло, так как были привлечены к анкетированию профсоюзные организации.

Полученные данные сведены в электронной таблице для дальнейшей обработки и создания графического материала. Также при выборе респондентов была поставлена задача: охватить как можно больше секторов экономики, организаций различных масштабов. Производственная демократия в казахстанской бизнес-среде преимущественно присутствует в средних и крупных предприятиях. Но если бы респонденты представляли только средние и крупные предприятия, то анализ был бы не полным и не отражал бы текущую ситуацию по исследуемому вопросу. 


\section{Результаты и обсуждения}

В зарубежной практике влияние участия работников в управлении организацией и трудовым коллективом, влияние уровня развития элементов производственной демократии на показатели охраны труды являются распространенным объектом для исследований. Это обусловлено тем, что возможность участия работников в управлении организацией была закреплена еще в положениях Всеобщей декларации прав человека 1948 г (Бабаева 2016:162).

Научный интерес к процессу становлении и внедрении в национальную и международную практику элементов производственной демократии сыграли такие нормы и рекомендации Международной организации труда (далее MOT), направленные на расширение прав трудящихся, как:

- Рекомендация № 94 «О консультациях и сотрудничестве между предпринимателями и трудящимися на уровне предприятия» от 1952 года;

- Рекомендация № 129 «О связях между администрацией и трудящимися на предприятии» от 1967 года;

- Конвенция № 135 «О защите прав представителей, трудящихся на предприятии и предоставляемых им возможностях» от 1971 года;

- Рекомендация № 143 «О защите прав представителей, трудящихся на предприятии и предоставляемых им возможностях» от 1971 года;

- Конвенция № 154 «О содействии коллективным переговорам» от 1981 года.

Исследователям было важно знать, какое влияние оказывает развитие практики участия работников в управлении организацией: на самих работников, на работодателей, на развитие организаций и пр.

На начальных этапах исследовательские работы влияния производственной демократии на трудовые отношения носили теоретический характер. Авторы проводили дискуссии по вопросам определения терминов, основного правового содержания производственной демократии, выдвигали гипотезы о возможном влиянии практики участия работников на те или иные аспекты функционирования организации, в том числе и на показатели охраны труда. Так, в 1984 году, группа авторов при поддержке UNESCO издала работу «Производственная демократия: участие работников, трудовые отношения и мотивация» (UNESCO:1984).

Вопросы влияния правовых аспектов производственной демократии на охрану труда были также рассмотрены в трудах П. Блумберга в 1969 году (Blumberg:1969), К. Бойль в 1995 году (Boyle:1995), М. Дербер в 1970 году (Derber:1970) и группой авторов С. М. Липсет, M. Трой, Дж. Колеман в 1977 году (Lipset, Trow, Coleman: 1977). Интересными являются труды американских авторов, которые видели в производственной демократии инструмент борьбы с расовой дискриминацией в различных штатах (Klare: 1982).

Позже появляются труды, основанные на сборе практических данных в сфере развития производственной демократии и его влияния на различные аспекты трудовых отношений. Так, в 2015 году Дупе А. А. провел исследование с участием 815 сотрудников различных организаций по вопросам влияния производственной демократии на различные аспекты эффективного функционирования организаций (Dupe 2015). Результаты исследования показали, что, действительно, высокий уровень производственной демократии, наличие элементов института участия работников в управлении организацией положительно влияют на ряд компонентов эффективной работы организации, в том числе на показатели текучести кадров, нарушения трудовой дисциплины и пр.

Таких исследований достаточно много, но выводы по ним относятся исключительно к тем регионам, в которых было проведено исследование. Результаты исследования, например, европейского трудового сообщества, могут быть неприменимыми для казахстанской сферы трудовых отношений. Наиболее близкими для казахстанского общества являются общества постсоветских государств. Существует большое количество исследований, посвященных правовым вопросам развития производственной демократии в организациях. Так, например, В.А. Сафонов в своем исследовании рассматривает условия, при наличии которых обеспечивается реальное участие работников в управлении организацией, обосновывается применение принципа их «частичного участия» (Сафонов 2014: 138). Большая часть русскоязычных научных трудов написана на основе анализа зарубежного опыта, оценки нормативно-правовых актов в сфере трудовых отношений.

Для заполнения данного пробела автором было проведено анкетирование сотрудников казахстанских организаций с целью определения влияния элементов производственной демократии на правовые аспекты трудовых отношений 
в условиях экономического кризиса как катализатора негативных процессов и нарушения прав трудящихся.
Автором была проведена оценка демократизации в организациях по 3-балльной шкале (таблица 1).

Таблица 1 - Оценка демократизации в организациях, баллы

\begin{tabular}{|l|c|}
\hline Утверждения & Баллы \\
\hline $\begin{array}{l}\text { Как минимум раз в месяц я разговариваю со своим непосредственным руководителем по вопросам } \\
\text { принятия тех или иных решений }\end{array}$ & 2,1 \\
\hline $\begin{array}{l}\text { В нашей организации руководитель доступен и в любое время можно подойти со своим вариантом } \\
\text { решения той или иной производственной задачи }\end{array}$ & 1,7 \\
\hline В нашей организации работники поощряются за проявленную инициативу & 1,2 \\
\hline Часто о процессе принятия важных решений работников не оповещают либо оповещают по факту & 2,7 \\
\hline В нашей организации созданы все условия для участия работников в управлении производством & 1,1 \\
\hline $\begin{array}{l}\text { В нашей организации весь акцент сделан только на работе, у работников нет ни времени, ни } \\
\text { возможности для участия в управлении производством }\end{array}$ & 2,6 \\
\hline Сотрудники в нашей организации не принимают участия в управлении & 2,4 \\
\hline $\begin{array}{l}\text { В нашей организации создан производственный совет или иной орган, который обеспечивает участие } \\
\text { работников в управлении производством/организацией }\end{array}$ & 1,3 \\
\hline
\end{tabular}

При максимальном значении 16 баллов (максимально развита производственная демократия), было набрано 10,4 балла, что является низким показателем. Данный результат дает возможность сделать вывод, что институт участия работников в управлении организацией развит недостаточно хорошо.

Далее было выявлено, что стиль управления персонала в них в большей степени директивный и авторитарный (рисунок 1).
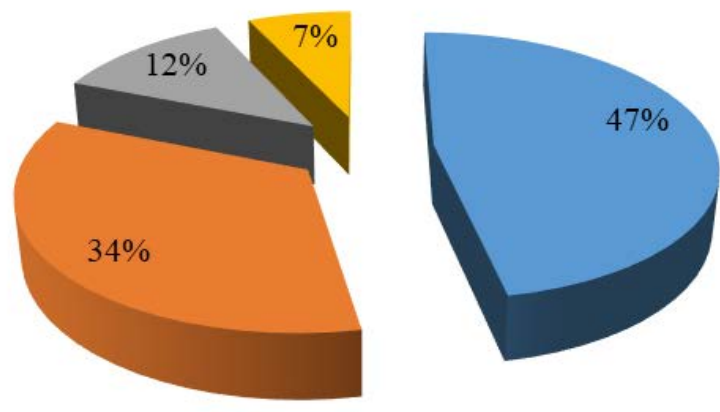

- Директивный

- Авторитарный

П Партнерский

ш Демократический

Рисунок 1 - Стили управления в казахстанских организациях, \% Примечание: источник - результаты опроса

Демократический стиль управления существует только в 7\% исследованных казахстанских организациях. На наш взгляд, это обусловлено не только неготовностью собственников бизнеса передать часть функций управления, но и неготовностью самих работников взять ответ- ственность за вопросы развития организации. Можно выделить следующие основные причины такого положения дел:

- отсутствие нормативной базы для развития производственной демократии с четким механизмом ее реализации; 
- опасения работников в части возложения на них повышенной материальной ответственности за принятие самостоятельных решений без соответствующего материального вознаграждения;

- низкий уровень лояльности работников к работодателям и пр.

На вопрос о факторах, которые могут положительно отразиться на скорости процесса развития производственной демократии, большая часть респондентов выбрала следующие варианты;

- материальная мотивация работников: премии, участие в прибыли $-65 \%$;

- снижение количества трудовых споров и конфликтов в организации $-29 \%$.

Также респондентами были выделены следующие барьеры, которые могут помешать развитию производственной демократии в организации:

- отсутствие правовой базы регулирования отношений в рамках производственной демократии $-26 \%$;

- отсутствие внутренней корпоративной документации регулирования отношений в рамках производственной демократии - 32\%;

- высокая стоимость на внедрение форм производственной демократии (дополнительные обучающие тренинги, семинары и пр.) - 16\%;

- непонятны цели и задачи производственной демократии $-49 \%$;

- нет свободного времени на реализацию функций управления, высокая загруженность на работе $-34 \%$;

- непосредственный руководитель не считает необходимым мое участие в управлении производством $-12 \%$;

- коллеги не считают необходимым участие в управлении производством - 21\%;

- будет сложно или невозможно практически использовать управленческие функции - 34\%;

- нет подходящих и необходимых для меня семинаров, тренингов и прочих методов обучения и развития $-17 \%$

- прошлый негативный опыт в практике участия в управлении организацией - $7 \%$.

Данное анкетирование проводилось в период экономического кризиса, связанного с мерами по борьбе с пандемией. Далее по результатам анкетирования были отобраны две группы организаций:

1 группа: организации с элементами производственной демократии - 10 организаций. Выделены следующие признаки производственной демократии: демократический стиль управ- ления, в котором руководство и собственники стремятся вовлекать работников к самоуправлению, наличие профессиональных союзов, а также факты создания временных представительств для решения кризисных ситуаций.

2 группа: организации с полным отсутствием практики участия работников в управлении организацией - 10 организаций.

То есть для оценки влияния уровня производственной демократии на показатели эффективности организации трудовых отношений выборочно были отобраны по 10 организаций из каждой группы для анализа динамики по следующим показателям:

- текучесть кадров за первое полугодие 2020 года в сравнении с аналогичными периодами 2019 и 2018 годов;

- темпы роста расходов на социальное обеспечение и заработную плату сотрудников;

- показатели нарушения трудовой дисциплины в организациях.

Для расчета текучести кадров за исследуемый период были использованы промежуточные финансовые отчеты организаций, находящиеся в свободном доступе. В рисунке 2 приведены результаты проведенных расчетов.

В рисунке 2 приведены средние показатели по 5 организациям из каждой группы. Как показывает график по второй группе организациям наблюдается резкий рост текучести кадров. Резкий прирост данного показателя увеличивает риски нарушения прав работников: незаконные увольнения, задержки заработной платы, увеличение рабочего времени и пр.

То есть, проведенный анализ дает возможность сделать вывод, что организации, где отсутствуют элементы производственной демократии, хуже переносят экономический кризис. Так, текучесть кадров в них за 1 полугодие 2020 года превысило аналогичные показатели за 2018 и 2019 годы почти в два раза.

Для расчета расходов на социальное обеспечение были также использованы данные отчетности организации, а затем рассчитан средний показатель. Было принято решение взять показатель расходов на одного сотрудника (рисунок 3 ).

Рисунок 3 демонстрирует, что в условиях стабильности выбранный показатель социальной ориентированности второй группы организаций значительно ниже показателей первой группы организаций. В условиях негативных внешних факторов средний показатель расходов на социальное обеспечение работников снижается почти в три раза. В первой группе организа- 
ций, где выявлены элементы производственной демократии, расходы увеличиваются и в кризисном периоде. В расходы на социальное обеспечение нами были включены: оплата обучения как сотрудников, так и их детей; транспортные расходы сотрудников; обеспечение питанием, предоставление бесплатного жилья» выделение разовой социальной помощи и др.

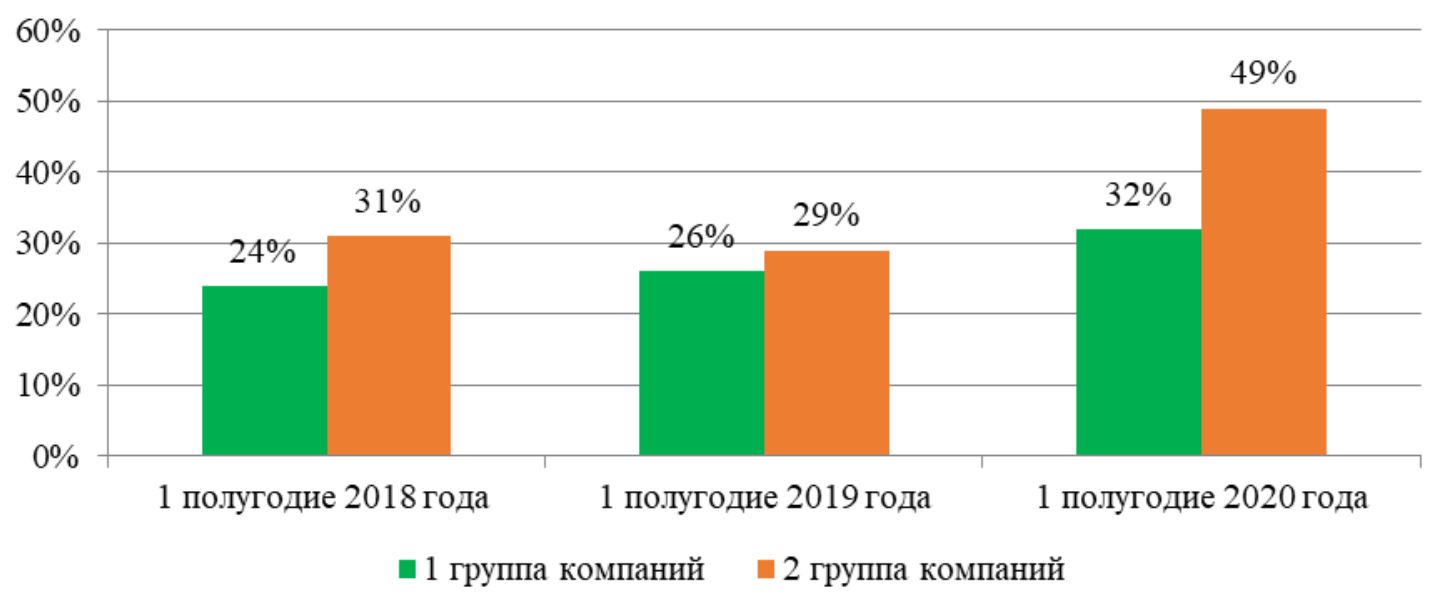

Рисунок 2 - Сравнительная динамика среднего показателя коэффициента текучести кадров в исследуемых группах организации, \% Примечание: составлено автором

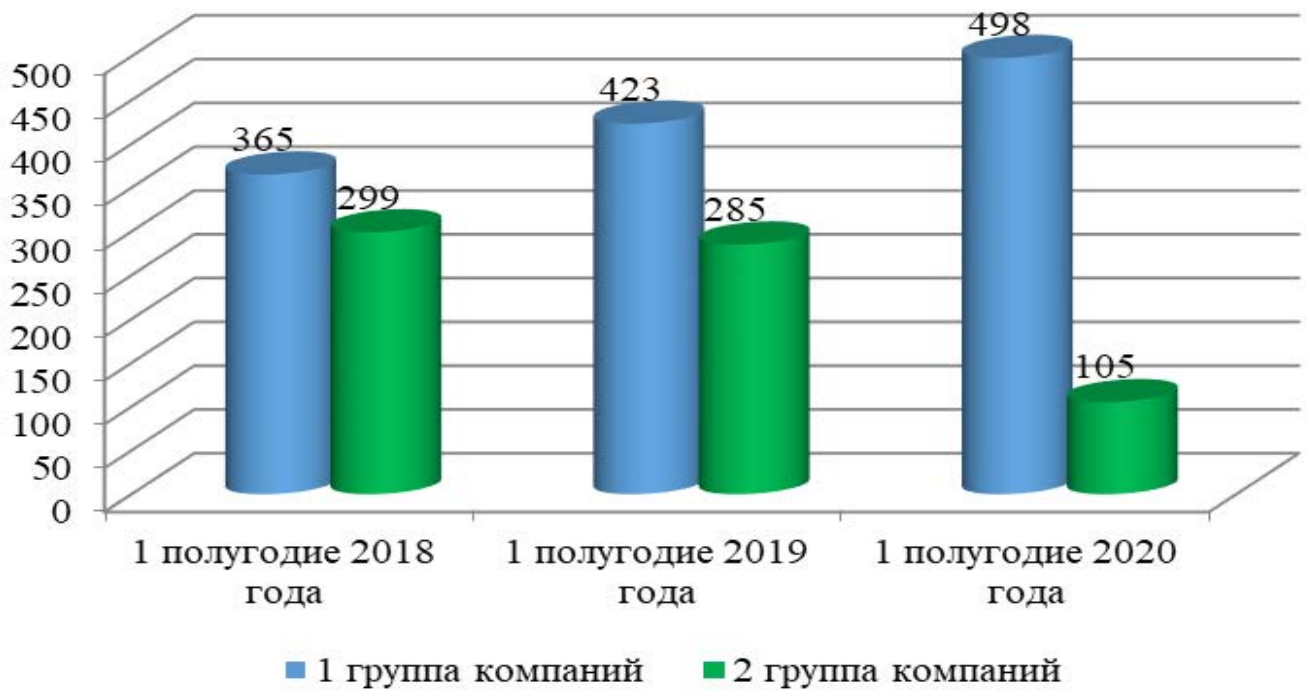

Рисунок 3 - Средний показатель расходов на социальное обеспечение, в среднем на одного работника за полугодия 2018, 2019, 2020 годов, тыс. тенге Примечание: составлено автором

То есть в кризисный период в организации, где не была развита производственная демократия, наблюдалось значительное снижение расходов на социальное обеспечение.
Вместе с этим, показатели нарушения трудовой дисциплины в двух группах организаций остались на прежнем уровне, а в некоторых организациях наблюдалось снижение. Нами 
был выбран следующий показатель по данной сфере - среднее количество фактов нарушения трудовой дисциплины за полугодие на 100 сотрудников.
Под нарушениями трудовой дисциплины нами подразумевались: опоздания на работу, нарушение правил безопасности на производственных участках и другие.

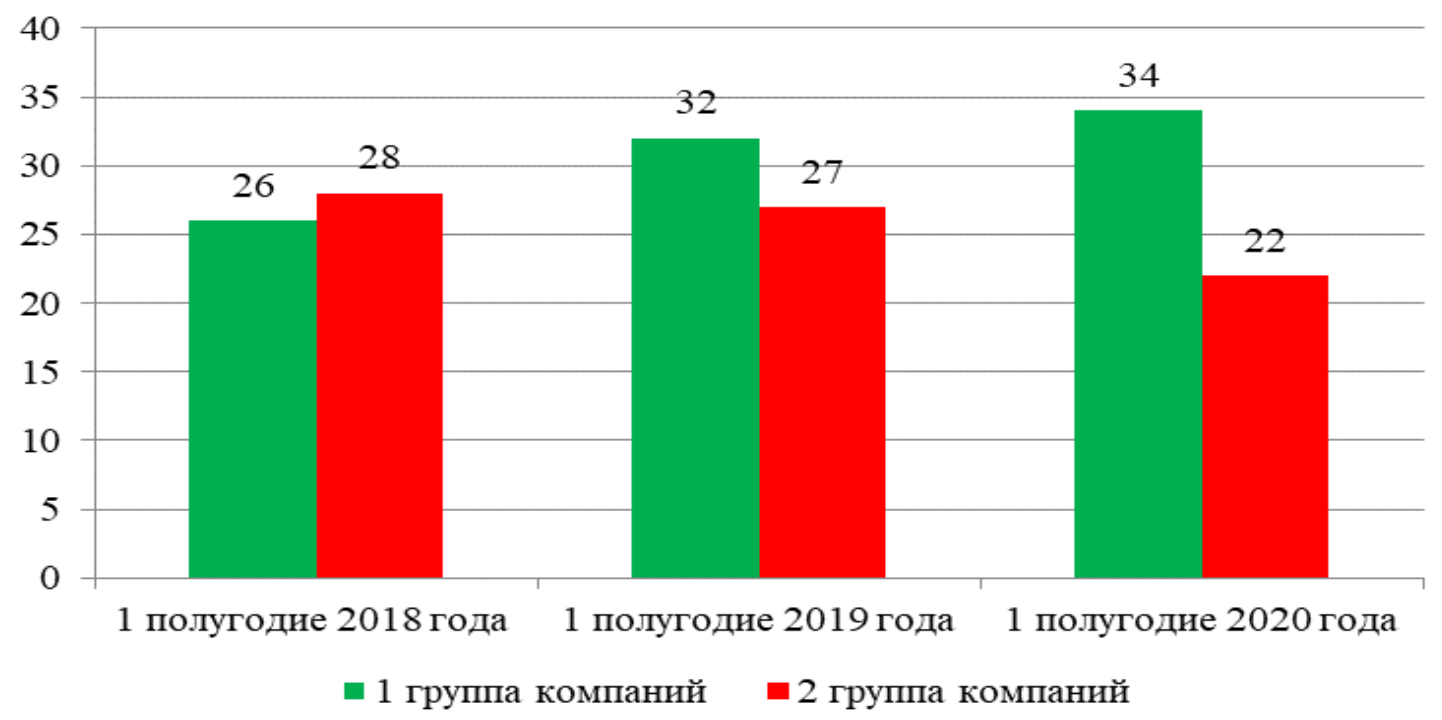

Рисунок 4 - Влияние наличия/отсутствия элементов производственной демократии на показатели нарушения трудовой дисциплины, факты нарушения трудовой дисциплины на 100 сотрудников

Примечание: составлено автором

\section{Заключение и выводы}

Таким образом, сотрудники организаций, где были выявлены признаки производственной демократии легче переносят экономический кризис. В них наблюдается сохранение низких и средних показателей текучести кадров, а также рост расходов на социальное обеспечение. При всех преимуществах развития института производственной демократии как инструмента защиты социально-трудовых прав работников существует ряд барьеров. Так, например, до настоящего времени не была создана правовая база для исследуемого института. В Трудовом кодексе Республики Казахстан отражены: права работников при составлении коллективных трудовых договоров, права на создание производственного совета по безопасности и охране труда, право с помощью профсоюзов и выборных представителей защищать и представлять работников. То есть рассматривается право работника на защиту и охрану своих прав, в которые не входит право на участие в управление организацией.
В казахстанских организациях, придерживающихся принципов производственной демократии, нет внутренней документации, которая бы регламентировала вопросы участия работников в управлении организацией. Работники привлекаются к решению управленческих вопросов, как правило, стихийно. Предоставление такого права является добровольным шагом самого собственника организации, внедряющего современные подходы и принципы управления организацией. Вместе с этим, положительный эффект внедрения производственной демократии организации очевиден. Производственная демократия и ее элементы положительно влияют на темпы социально-экономического развития организации, могут выступать одним из ключевых инструментов охраны труда.

Таким образом, для ускоренного развития производственной демократии и ее элементов в казахстанских организациях необходимо:

- включить в государственную стратегию социально-экономического развития необходимость реализации мероприятий по развитию производственной демократии в казахстанских 
организациях: информирование, консультирования, методологическая поддержка, совершенствование законодательства;

- выделить гранты на научные исследования и мониторинг процесса развития производственной демократии в казахстанских организациях, а также оценки его влияния на различные аспекты трудовых отношений;
- разработать типовую форму внутрифирменного документа, утверждающего права и регламентирующего порядок участия работников в управлении организацией. Данный внутренний документ может быть как частью «Кадровой политики компании», так и выделен в отдельную внутрифирменную норму.

\section{Литература}

Blumberg P. Industrial Democracy: The Sociology of Participation. Published by Schocken Books Inc., Park Avenue, New York, 1969

Boyle K., The UAW and the Heyday of American Liberalism, 1945-1968, 1995

Derber M., The American Idea of Industrial Democracy, 1865-1965, 1970

Dupe Adesubomi Abolade Impacts of Industrial Democracy on Organizational Performance (Case Study of Selected Private and Public Sector Organizations in Lagos State, Nigeria). Journal of Research in Social Sciences-JRSS June 2015 Vol: 3 Number 2. ISSN: (E) 2306-112X

Industrial democracy: participation, labour relations and motivation. Published quarterly by UNESCO Vol. XXXVI, No. 2, 1984.

Karl E. Klare. The Quest for Industrial Democracy and the Struggle Against Racism: Perspectives from Labor Law and Civil Rights Law. HeinOnline -- 61 Or. L. Rev. 1591982

Lipset S.M., Trow M. and Coleman J., Union Democracy: The Inside Politics of the International Typographical Union, 1977

Бабаева О. Н. «Право работников участвовать в управлении организацией: от декларации к гарантии» Вестник ВГУ. Серия: Право. 2016 - С. $161-170$

Запесоцкий А. С. Участие работников в управлении организацией как фактор профилактики социально-трудовых конфликтов. - СПб.: СПбГУП. - 2019. - 256 с.

Сафонов В. А. Участие работников в управлении организацией: очерк теории. Трудовое и социальное право. Российский юридический журнал. 2014, - С. 138-145

Рекомендация № 94 «О консультациях и сотрудничестве между предпринимателями и трудящимися на уровне предприятия» от 1952 года;

Рекомендация № 129 «О связях между администрацией и трудящимися на предприятии» от 1967 года;

Конвенция № 135 «О защите прав представителей трудящихся на предприятии и предоставляемых им возможностях» от 1971 года;

Рекомендация № 143 «О защите прав представителей трудящихся на предприятии и предоставляемых им возможностях» от 1971 года.

Конвенция № 154 «О содействии коллективным переговорам» от 1981 года.

\section{References}

Babaeva O. N. «Pravo rabotnikov uchastvovat' v upravlenii organizaciej: ot deklaracii k garantii» [The right of employees to participate in the management of the organization: from declaration to guarantee] Vestnik VGU. Serija: Pravo. 2016 - S. 161 -170

Blumberg P. (1969) «Industrial Democracy: The Sociology of Participation». Published by Schocken Books Inc., Park Avenue, New York.

Boyle K., The UAW and the Heyday of American Liberalism, 1945-1968, 1995

Derber M., The American Idea of Industrial Democracy, 1865-1965, 1970

Dupe Adesubomi Abolade «Impacts of Industrial Democracy on Organizational Performance (Case Study of Selected Private and Public Sector Organizations in Lagos State, Nigeria). Journal of Research in Social Sciences-JRSS June 2015 Vol: 3 Number 2.ISSN: (E) 2306-112X

Industrial democracy: participation, labour relations and motivation. Published quarterly by UNESCO Vol. XXXVI, No. 2, 1984

Karl E. Klare. (1982) The Quest for Industrial Democracy and the Struggle Against Racism: Perspectives from Labor Law and Civil Rights Law. HeinOnline - 61 Or. L. Rev. 159.

Konvencija № 135 «O zashhite prav predstavitelej trudjashhihsja na predprijatii i predostavljaemyh im vozmozhnostjah» ot 1971 goda [Convention No. 135 «On the Protection of the Rights of Workers' Representatives in the Enterprise and the Opportunities provided to them» of 1971];

Konvencija № 154 «O sodejstvii kollektivnym peregovoram» ot 1981 goda [Convention No. 154 «On the Promotion of Collective Bargaining» of 1981]. 
Lipset S.M., Trow M. and Coleman J., (1977) Union Democracy: The Inside Politics of the International Typographical Union.

Rekomendacija № 94 «O konsul’tacijah i sotrudnichestve mezhdu predprinimateljami i trudjashhimisja na urovne predprijatija» ot 1952 goda [Recommendation No. 94 «On consultation and cooperation between entrepreneurs and workers at the enterprise level» of 1952];

Rekomendacija № 129 «O svjazjah mezhdu administraciej i trudjashhimisja na predprijatii» ot 1967 goda [Recommendation No. 129 «On relations between the administration and workers in the enterprise» of 1967];

Rekomendacija № 143 «O zashhite prav predstavitelej trudjashhihsja na predprijatii i predostavljaemyh im vozmozhnostjah» ot 1971 goda [Recommendation No. 143 «On the protection of the rights of workers' representatives in the enterprise and the opportunities provided to them» of 1971.]

Safonov V. A. Uchastie rabotnikov v upravlenii organizaciej: ocherk teorii. Trudovoe i social'noe pravo. Rossijskij juridicheskij zhurnal. [Participation of employees in the management of the organization: an essay of the theory. Labor and social law. Russian Law Journal.] - 2014. - S. 138-145

Zapesockij A. S. Uchastie rabotnikov v upravlenii organizaciej kak faktor profilaktiki social'no-trudovyh konfliktov [Participation of employees in the management of the organization as a factor in the prevention of social and labor conflicts]. $-\mathrm{SPb}$.: SPbGUP. - 2019. - $256 \mathrm{~s}$ 